\title{
Do Foreign Investors Care About Labor Market Regulations?
}

\author{
Beata Smarzynska JAVORCIK* \\ and \\ Mariana SPATAREANU**
}

\begin{abstract}
This study takes a new look at the regulatory determinants of foreign direct investment (FDI) by asking whether labor market flexibility affects FDI flows across 25 Western and Eastern European countries. The analysis is based on firm level data on new investments during the 1999-2001 period. We employ a variety of labor market flexibility measures that capture different aspects of labor laws along with a comprehensive set of controls for business climate characteristics. Indices of labor market regulations reflect the flexibility of individual and collective dismissals, the length of the notice period, and the required severance payment. The results suggest that greater flexibility in the host country's labor market relative to that in the investor's home country is associated with larger FDI inflows, and this effect is found to be stronger in the case of transition economies. The findings indicate that as the labor market flexibility in the host country increases from inflexible (e.g. Slovakia) to flexible (e.g. Hungary), the volume of investment increases by between 14 and 18 percent. FDI in service sectors appears to be more affected than investments in manufacturing.
\end{abstract}

World Bank Policy Research Working Paper 3275, April 2004

The Policy Research Working Paper Series disseminates the findings of work in progress to encourage the exchange of ideas about development issues. An objective of the series is to get the findings out quickly, even if the presentations are less than fully polished. The papers carry the names of the authors and should be cited accordingly. The findings, interpretations, and conclusions expressed in this paper are entirely those of the authors. They do not necessarily represent the view of the World Bank, its Executive Directors, or the countries they represent. Policy Research Working Papers are available online at http://econ.worldbank.org.

\footnotetext{
*World Bank and CEPR, Development Economics Research Group, 1818 H Street, NW; MSN MC3-303; Washington, DC, 20433. Email: bsmarzynska@worldbank.org

${ }^{* *}$ Washington University in St. Louis and World Bank, Development Economics Research Group, 1818 H Street, NW; MSN MC3-303; Washington, DC, 20433. Email: mspatareanu@worldbank.org.

The authors would like to thank Mathias Busse, Holger Görg, Jan Rutkowski and Maurice Schiff for helpful discussions and suggestions.
} 


\section{Introduction}

While the existing empirical literature on foreign direct investment (FDI) has examined the effect of various regulatory determinants on investment flows, ${ }^{1}$ no attention has been paid to one key aspect of government regulations, namely the flexibility of labor markets, despite the fact that both anecdotal evidence and the theoretical literature suggest that it ought be important. For instance, a recent issue of the Korean Times carried a headline stating that "Labor Market Flexibility [is] Key to Attracting Foreign Investment."2 Similarly, investor surveys often list "flexibility in hiring and laying off workers" as one of the main concerns of foreign investors considering entering transition economies and developing countries (Moran 1998, p. 89). This view is also echoed in a theoretical paper by Haaland, Wooton and Faggio (2003) who demonstrate a trade-off between FDI incentives and labor market flexibility and conclude that a country with a more flexible labor market (i.e., lower redundancy payments) should find it easier to attract FDI. To the best of our knowledge, the only empirical analysis of this question can be found in an unpublished paper by Dewit, Görg and Monagna (2003), which considers the impact of labor laws on FDI flows within the OECD countries in 1989 and 1998 and finds that an unfavorable employment protection differential between a domestic and a foreign location is inimical to FDI. ${ }^{3}$

This paper aims to fill the gap in the literature by asking whether the differences in labor market flexibility between source and host countries affect the location decisions of multinationals. Unlike the work of Dewit et al.(2003), our analysis is based on firm level data. More precisely, we use information on new subsidiaries established by the largest 10,000 European companies in 25 Western and Eastern European countries during 1998-2001. The information comes from a commercial database, Amadeus, compiled by Bureau van Dijk. One of the advantages of employing firm level data is that it allows to explicitly control for the characteristics of investing firms, which affect their investment decisions, such as a firm size,

\footnotetext{
${ }^{1}$ Wei (2000) examined the consequences of FDI incentives and restrictions on direct investment inflows, Hines (1996) and Devereux and Griffith (1998) the effect of taxation, Javorcik (forthcoming) the impact of intellectual property protection, Keller and Levinson (2002) and Smarzynska and Wei (2001) the effect of environmental standards.

${ }^{2}$ July 19, 2002.

${ }^{3}$ Görg (2003) addresses a similar question using the data on the stock of US outward FDI and focusing only on the level of labor market flexibility in a host country rather than the differential between the home and host economies, as is done in Dewit et al. and this study.
} 
previous FDI experience and the nature of the business (i.e., manufacturing versus services). We also consider a specification which takes into account unobserved investor characteristics.

Western European economies and the transition economies of Eastern Europe are suitable for studying this question, because they offer large variation in terms of labor market flexibility. In both Western and Eastern Europe we can find economies with highly inflexible labor markets (Portugal and the Slovak Republic) as well as countries affording employers relative freedom in hiring and firing decisions (Denmark and Romania).

We employ a variety of labor market flexibility measures that capture different aspects of the labor laws along with a comprehensive set of controls for business climate characteristics. The former include indices reflecting flexibility in individual dismissals, flexibility in collective layoffs, length of the notice period and the required severance payment, compiled by Djankov et al. (2003), as well as a proxy for flexibility in hiring and firing practices from the Global Competitiveness Report 2001-2002 (GCR) produced jointly by the Geneva-based World Economic Forum and the Center for International Development at Harvard University. Moreover, we control for the presence of restrictions on FDI inflows, protection of property rights, level of corporate taxation and quality of governance. Finally, we include proxies for market size and labor costs.

The results suggest that more flexibility in the host country's labor market relative to that in the investor's country is associated with a greater probability of investment taking place as well as with a larger volume of investment. The magnitude of the effect is economically meaningful. For instance, as the flexibility of the host country labor market increases from the level of France (inflexible) to the level of the United Kingdom (flexible), the volume of investment goes up by between 12 and 24 percent depending on the measure employed. When we interact the effect of labor market regulation with a dummy for transition countries, we find that investors entering these economies are even more sensitive to labor market regulation. For example, a change from the situation in Slovakia to that in Hungary results in a 14 to 18 percent increase in FDI volume. Moreover, as expected, the magnitude of the effect is larger for firms operating in service sectors than in manufacturing.

The paper is structured as follows. In the next section, we discuss the empirical model, the data and the variable definitions. Then we present the empirical results. The last section contains concluding remarks. 


\section{Empirical Strategy}

\section{Model and Estimation Issues}

The basic question we seek to answer is whether labor market flexibility affects the flow of foreign direct investment across countries. In doing so we also consider a number of other potential determinants of location choice, as suggested by the existing literature. ${ }^{4}$ We employ two empirical strategies to address this question. First, we focus on the location on foreign subsidiaries ignoring the size of investment. We estimate a fixed-effects logit model

$$
\begin{aligned}
& F D I_{i c}=1 \text { if } F D I_{i c}^{*}>0 \\
& F D I_{i c}=0 \text { otherwise } \\
& \text { where } \\
& F D I_{i c}^{*}=d_{i}+X_{c} \beta_{1}+\beta_{2} \text { Flexibility }_{i c}+u_{i c}
\end{aligned}
$$

where the dependent variable takes on the value of one if firm $i$ has invested in country $c$, and zero otherwise. For each firm the number of observations is equal to the number of possible destination countries in the sample. To control for unobserved firm characteristics, firm specific dummy variables $\left(d_{i}\right)$ are employed. On the right hand side we include the difference in the labor market flexibility between the source and the host country $\left(\right.$ Flexibility $_{i c}=$ Flexibility $_{i}-$ Flexibility $_{c}$ ) as well as other controls for host country characteristics $\left(X_{c}\right)$. Since our prior is that more flexible labor regulation in the host economy relative to the source country will attract foreign investment, we expect $\beta_{2}<0$.

Then we focus on the size of investment and estimate the following equation

$$
\ln \left(F D I \text { volume }_{i c}+1\right)=\alpha+X_{i} \delta_{1}+X_{c} \delta_{2}+\delta_{3} \text { Flexibility }_{i c}+\varepsilon_{i c}
$$

where the volume of investment undertaken by firm $i$ in country $c$ is regressed on characteristics of firm $i$ and its home country $\left(X_{i}\right)$, variables specific to potential FDI destinations $\left(X_{c}\right)$ and the difference between the host and the source economy in terms of labor market regulations $\left(\right.$ Flexibility $\left._{i c}\right)$. Again we expect $\delta_{3}$ to be negative. The number of observations for each firm is equal to the number of potential investment destinations, with the FDI volume equal zero for countries in which firm $i$ does not have any investments. Since taking the logarithm would lead

\footnotetext{
${ }^{4}$ For a literature review on FDI determinants see Wheeler and Mody (1992) and Markusen (1995).
} 
to losing all observations for which FDI volume takes on the value of zero, we add one before taking the $\log$.

Given that most firms have subsidiaries only in some of the 25 possible destination countries considered and some firms have no subsidiaries at all, in a large number of cases the dependent variable is equal to zero. Therefore, we employ the Tobit model, as using OLS would lead to inconsistent estimates.

The choice of the models is determined by data availability. As explained below, our dataset contains a comprehensive listing of the existing subsidiaries of firms included in the sample, but the information on the volume of investment is available only for a subset of them. The logit model allows us to maximize the sample coverage, while the Tobit regression enables us to examine the determinants of investment volume and thus the two approaches are complementary.

\section{Data Description}

The data used in this study come from the commercial database Amadeus compiled by Bureau van Dijk, which contains comprehensive information on approximately 5 million companies operating in 35 European countries. In addition to the standard financial statements, Amadeus includes comprehensive information about the ownership structure of firms, which allows us to identify ownership stakes held by each company in entities located in other countries. We are thus able to construct a unique data set containing detailed information about European firms and all of their domestic and foreign subsidiaries.

We focus our attention on the largest 10,000 firms operating in Europe ${ }^{5}$ (with the size measured by the value of total assets in 1999) and their subsidiaries located in 17 Western European and 8 Central and Eastern European countries, including Bulgaria, the Czech Republic, Hungary, Poland, Ukraine, Romania, Latvia and the Slovak Republic. The last three countries are not included in all regressions due to missing observations on some investment climate variables.

\footnotetext{
${ }^{5}$ The group of the largest 10,000 European firms includes 338 companies headquartered in Eastern European countries. These are: Bosnia and Herzegovina, Bulgaria, the Czech Republic, Estonia, Croatia, Hungary, Latvia, Lithuania, Poland, Romania, Russia, Slovakia, Slovenia, Ukraine, Yugoslavia.
} 
The choice of host countries considered is driven by two considerations. First, by the fact that information on the size of investment is available only for European subsidiaries, and second, by our decision to restrict the analysis to subsidiaries established between 1998 and 2001. We construct the data set on new subsidiaries by comparing the subsidiary listings for companies included in both the 1998 and 2001 versions of the Amadeus database. ${ }^{6}$ The ownership information pertains mostly to year 2000 and in some cases to 1999. If a firm has more than one subsidiary in a given country, we focus our attention on the one with the highest value of a parent company's equity participation. In the sample, we also include non-investors, i.e., firms without any subsidiaries in foreign countries. ${ }^{7}$

After deleting firms with missing information and removing outliers, ${ }^{8}$ the data set contains 7,150 parent firms with 7,077 subsidiaries in 22 to 25 destination countries (depending on the specification), including the home country, of which 3,701 are foreign subsidiaries. The number of potential observations in our sample is thus equal to 7,150 x $22=157,300$ (or 7,150 x $25=178,750)$ investment decisions at the firm level.

\section{Variables Definitions}

The dependent variable in Equation (1) is equal to one if the database indicates the existence of firm $i$ 's subsidiary in country $c$. In Equation (2), we construct FDI volume by multiplying the percentage of equity owned by firm $i$ in its subsidiary located in country $c$ by the total assets of the subsidiary. If firm $i$ has more than one subsidiary in country $c$ we use the largest investment. If no subsidiary exists, the variable takes on the value zero. All information from the Amadeus database presented in national currencies is converted to U.S. dollars using the average market exchange rate for the given year from the IMF's International Financial Statistics.

In addition to accounting for the conditions in the host country, our data set provides us with an opportunity to control for the characteristics specific to parent companies (we do so only in Equation (2) as Equation (1) includes parent fixed effects). We control for firm size using the

\footnotetext{
${ }^{6}$ We chose not to go further back in time as the earlier versions the database were much smaller in size and contained very limited information on subsidiaries in Eastern Europe.

${ }^{7}$ Such firms drop out from the fixed effect logit estimation but are included in the tobit regressions.

${ }^{8}$ Firms with negative or unusually large values for sales, total assets or employment were dropped from the sample.
} 
value of total assets and for the international experience by including the total number of firms' foreign subsidiaries at the beginning of the period in question, 1998. ${ }^{9}$ We anticipate that both variables will be positively correlated with the decision to undertake FDI. We also take into account the population size and the GDP per capita of the source country expecting that more FDI is likely to come from richer countries and economies with higher labor costs.

Since the purpose of our paper is to test for the effect of labor market flexibility on the multinational firms' decision to invest in various countries, it is crucial to have plausible measures of labor market regulations. The first measure used in our analysis is the Index of Flexibility of Hiring and Firing Practices from the Global Competitiveness Report 2001-2002 published jointly by the Geneva-based World Economic Forum and the Center for International Development at Harvard University. It is a country specific index that quantifies the average response to the survey question: "Is hiring and firing of workers impeded by regulations or flexibly determined by employers?." It takes on the value of 7 for a very flexible labor market and 1 in the case of the most rigid ones. Since it is based on the views of "business practitioners" in each country, it captures not only laws on the books but also their enforcement. ${ }^{10}$

We also include four additional measures, compiled by Djankov et al. (2003), reflecting the strength of employment protection legislation, which relates to employers' liberty to lay off workers. These are: the Index on the Flexibility of Individual Dismissal Procedures, the Index on the Flexibility of Collective Dismissal Procedures, the Index on Notice and Severance Payment and the Total Index on Rules of Dismissal. These indices rely on information collected in 2001 thus matching well the time period of our sample. Their values range from 0 to 12 , with 0 representing very strict rules of dismissal and 12 the most ample ones. Thus, the higher the number, the less costly it is for the employer to dismiss workers. Note that the above variables are country specific but, since firing costs are usually comparable across firms and industries as they are set by nationwide legislation, the use of country level data is appropriate.

As illustrated in Charts 1 and 2 there is a large variation in the 25 countries considered in our sample in terms of labor market flexibility. In both Western and Eastern Europe we can find economies with inflexible labor markets (Portugal and Slovak Republic) as well as countries

\footnotetext{
${ }^{9}$ Note that the number of subsidiaries pertains investments located all over the world, not just in twenty-five countries considered in our sample

10 This index has also been employed by Görg (2002).
} 
affording employers relative freedom in hiring and firing decisions (Denmark and Romania). While there are some differences in individual rankings between the GCR and Djankov index, the two measures appear to be highly correlated (see Chart 3). Recognizing that impediments to adjusting employment numbers constitute a push factor encouraging firms to transfer production out of their own country as well as a pull factor enticing firms to enter economies with flexible rules, we focus on the difference in labor market flexibility between the home and host country. Thus lower values of the variable correspond to greater flexibility being present in the host country and we expect to find a negative relationship between Flexibility ${ }_{i c}$ and the likelihood or volume of investment.

Turning to other host country specific characteristics, we control for factors commonly mentioned in the literature as determinants of FDI, including proxies for market size (population size) and labor costs in the host country (GDP per capita in current US dollars). Both variables come from the World Bank's World Development Indicators. We expect that larger markets will attract investors while higher labor costs will act as a deterrent.

We also control for various aspects of business climate in the host country. The first control is the FDI Restrictions Index derived by Wei (2000) based on reading the detailed country reports produced by PricewaterhouseCoopers. The index focuses on four areas: the existence of foreign exchange controls (which may interfere with foreign firms' ability to import intermediate inputs or repatriate profits abroad), exclusion of foreign firms from strategic sectors (e.g., defense industry, media), exclusion of foreign firms from other sectors, and restrictions on the share of foreign ownership. Each of these four dimensions is represented by a variable taking on the value of one in the presence of restrictions and zero otherwise. The overall index is defined as the sum of these variables and ranges from zero (no restrictions) to four (restrictions present in all areas).

The second control is the Index of Strength of Property Rights, which comes from the Global Competitiveness Report 2001-2002. It is based on an extensive survey of managers who were asked to rate on the scale 1 to 7 whether the "property rights [in a given country] are clearly delineated and protected by law." Subsequently, the arithmetic mean of all responses by country was reported. A score of 7 corresponds to countries with well protected property rights and 1 to the countries with little or no protection. This variable is intended to capture the country specific 
risk that multinational firms may face from possible expropriation of assets, insecurity of property rights and contracts.

Another potentially important factor influencing the FDI location is the level of corporate taxation in the host country, as demonstrated by Hines (1996) and Devereux and Griffith (1998). We employ the corporate tax rates as reported by PricewaterhouseCoopers. All taxes are expressed in percentages; if several rates apply, the highest one is used.

Finally, we also control for the quality of governance using the measure derived by Kaufmann, Kraay and Zoido-Lobaton (KKZ) and described in detail in their 1999 publication. When constructing their measure based on data from 17 different sources, the authors assume that the available individual country ratings reflect both some true but unobserved level of governance and sampling variations and perception errors. The unobserved "true" level of governance can be backed out statistically (assuming a linear unobserved component specification). The resulting estimates range from -2.5 to 2.5 , with a mean of zero and standard deviation of one. The higher the estimate for each country, the less corrupt and better governed the country. The KKZ index can be viewed as a more sophisticated and improved version of the popular Transparency International Corruption Perceptions Index.

As can be seen in Table 1, a large degree of heterogeneity is found in terms of business environment in host countries in our sample. Transition economies usually rank low with respect to governance measures and property rights protection. However, the picture is mixed with regard to FDI incentives and labor market flexibility and corporate taxation, as in both Western and Eastern Europe we find countries with very different scores in those areas. For instance, while some transition economies, especially Hungary, Czech Republic and Poland, have no or very few restrictions, others, such as Ukraine, have restrictions in all categories. Similarly, while the Slovak Republic has the highest corporate tax rate, Hungary offers the lowest one in the sample. 


\section{Estimation Results}

\section{FDI Determinants}

We begin by examining the determinants of FDI, other than labor market flexibility. We estimate a logit model with fixed effects for each investing company. ${ }^{11}$ The results are presented in the first column of Table 2. We find positive and significant coefficients on the host country's population size and GDP per capita, suggesting that larger and richer countries are more attractive investment destinations. Further, the data suggest that lower restrictions on FDI and better governance are associated with a higher probability of FDI taking place. As anticipated, the index of property rights protection bears a positive sign but does not appear to be statistically significant. The coefficient on the corporate tax rate is positive and significant, which is somewhat counterintuitive, yet not unusual in the literature on determinants of FDI. Finally, a dummy for transition countries is positive and significant indicating that these countries have a higher probability of receiving FDI than what would be predicted given their economic and regulatory environment.

\section{Effect of Labor Market Flexibility}

Next, we turn our attention to labor markets and proceed by including one by one five measures capturing differences in labor market flexibility between the investor's home country and the host economy. Since higher values of these variables correspond to the labor market being more flexible at home relative to the host country, we expect the estimated coefficient to be negative if greater flexibility in the host economy is attractive to investors. The first measure included is the GCR Index of Flexibility of Hiring and Firing practices (Table 2). Its coefficient is negative and statistically significant at the 1 percent level, thus suggesting that indeed, other things being equal, the more flexible the host country's labor market is relative to that in the source country, the higher the probability of FDI taking place. The same conclusion is reached when the Total Index on Rules for Dismissal, compiled by Djankov and al. (2003), as well as each of its components, i.e., Index of Flexibility of Individual Dismissal Procedures, Index of Flexibility of Collective Dismissal Procedures and Index of Notice and Severance Payment are

\footnotetext{
${ }^{11}$ Note that in the fixed effect logit firms without any investment projects drop out of the estimation.
} 
used. In all four cases the indices have negative and highly significant coefficients. Including the labor market variables has little impact on the signs or significance levels of other determinants of FDI, with the exception of the property rights protection index, which becomes positive and statistically significant in most regressions, confirming the belief that a stable and well-enforced property rights system is crucial to attracting foreign investors.

The regressions presented so far constrain the effects of labor market flexibility on FDI to be equal across countries. This may be a strong assumption since the sample of host countries in our data set includes industrial as well as transition economies. To relax this assumption we introduce an interaction between the labor market flexibility measures and a dummy variable for transition countries and repeat the exercise. We find that both the labor market variables and the interaction terms are negative and highly statistically significant, which suggests that as far as transition economies are concerned, the flexibility of the labor markets is an even more important factor in the decision of the multinational to locate there.

Next, we focus our attention on explaining the determinants of FDI volume rather than the mere fact of investment taking place. We employ the Tobit estimation technique and follow the same procedure of consecutively adding the labor market variables to the regression, keeping the same controls as before. In addition, we include some source country characteristics, such as the logarithm of the GDP per capita and the population size. ${ }^{12}$ We also account for the characteristics of the investing firms, in particular their size and their international experience. The former is captured by the logarithm of firm's total assets and the latter by the logarithm of the total number of firms' foreign subsidiaries in 1998.

The results, presented in Table 3, confirm our previous findings of the difference in the labor market flexibility between the source and the host country being an important factor affecting the location decision of multinational firms. All five indices of the relative labor market flexibility have the expected negative signs and are statistically significant at the one percent level. This result is robust to including the interactions with a transition country dummy. As for the interaction terms themselves, only in two out of five regressions they suggest that the effect of labor market regulation on investment volume is larger for transition countries than for the full sample.

\footnotetext{
${ }^{12}$ Note that the number of observations is smaller in Tobit than in fixed effects logit regressions due to missing observations on investment volume.
} 
The other controls for host country characteristics have the same signs as in the previous table and are highly significant. The only exception is the host country GDP per capita, which now bears a negative and statistically significant sign. The negative association between this variable and the investment volume is consistent with the view that GDP per capita can be interpreted as an (albeit imperfect) proxy for the level of labor costs. As for the investor characteristics, we find that larger firms as well as firms with greater international experience are more likely to undertake FDI. The same is true of firms headquartered in richer and larger countries. The latter effect is statistically significant only in four regressions.

The magnitude of the effects is economically meaningful. As the flexibility of the host country labor market increases from the level of France (inflexible) to the level of the United Kingdom (flexible) the volume of investment goes up by between 12 and 24 percent depending on the labor regulation proxy employed. The effect is equally large for transition countries-a change from the situation in Slovakia to that in Hungary results in a 14 to 18 percent increase in FDI volume.

\section{Robustness Checks}

As a robustness check and an attempt to increase the number of transition economies included in the regression we drop the measure of FDI restrictions and the corporate tax rates from the regressions. This allows us to include in the regressions three additional transition economies: Romania, Latvia and the Slovak Republic. Again we estimate the fixed effect logit and the Tobit model and follow the same approach of consecutively adding the labor market flexibility variables. The results, presented in Tables 4 and 5, indicate that our previous findings are robust to increase the number of countries in the dataset. As before, the labor market flexibility proxies are all negative and statistically significant, reinforcing our previous findings. The only difference comes from the interactions between the labor market variables and the transition country dummy in the Tobit model. The relationship between the value of investment and labor market flexibility appears to be weaker for transition countries than for the sample as a whole and in two cases it even breaks down for transition countries. In all regressions, however, the link between labor market flexibility and the value of FDI in Western European economies remains robust. 
As yet another robustness check (not presented here to conserve space), we applied the same approach to all existing rather than only new subsidiaries of the top 10,000 European companies. In the case of multiple subsidiaries being held by the same parent company in a given host country, we included only the largest investment in the sample, regardless of when the subsidiary was created. The rationale for this exercise was that multinational companies tend to respond quickly to change in business environment by relocating their activities to other places. As expected, we obtained results consistent with our previous findings. Labor market flexibility variables were again consistently negative and statistically significant, reinforcing our earlier results that labor market conditions are a key determinant of both the location and the volume of FDI.

\section{Manufacturing versus Service Sectors}

If labor market flexibility indeed matters for the location choice of multinational companies, then we would expect it to be of greater importance to multinationals in more laborintensive sectors. Since services are usually more labor intensive than manufacturing, and since our rich database includes information about the industry in which the investing company operates, we examine whether the two types of sectors respond differently to labor market regulations. To do so, we introduce an interaction between a dummy variable equal to one for service sectors and the proxies for labor market flexibility and follow the same empirical strategy as before. The results, presented in Tables 6 and 7, confirm our priors. We find that the interaction terms are statistically significant and negative in all cases. That is, labor market flexibility matters more for firms in service sectors than those in manufacturing industries.

\section{Conclusions}

Labor market rigidities are often cited as one of the factors that multinationals take into account when deciding on a prospective host country for invetsment, yet hardly any attention has been paid to this issue in the empirical literature. This paper is an attempt to further our knowledge in this area. Using firm level data on new foreign investments undertaken by 
European companies during the period 1999-2001 and a comprehensive set of labor market indicators, we examine the impact of labor market flexibility on FDI inflows into 25 European countries.

Our empirical findings are as follows. The FDI location choices as well as the volume of FDI are negatively related to labor market flexibility. That is, the more flexible the labor market in the host economy relative to the investor's home country, the higher the likelihood of investment in the host country. As expected, this effect matters more for firms operating in service sectors than for manufacturing companies. 


\section{References}

Devereux, Michael and Rachel Griffith. 1998. "Taxes and the Location of Production: Evidence from a Panel of US Multinationals," Journal of Public Economics, 68: 335-367.

Dewitt, Gerda, Holger Görg and Catia Montagna. 2003. "Should I Stay or Should I Go? A Note on Employment Protection, Domestic Anchorage, and FDI," mimeo, University of Nottingham.

Djankov, Simeon, Rafael La Porta, Florencio Lopez-de-Silanez, Andrei Shleifer and Juan Carlos Botero. 2003. The Regulation of Labor", NBER Working Paper No. 9756.

Görg, Holger. 2003. "Fancy a Stay at the "Hotel California"? Foreign Direct Investment, Investment Incentives, and Exit Costs," mimeo, University of Nottingham.

Haaland, Jan, Ian Wooton and Giulia Faggio. 2003. "Multinational Firms: Easy Come, Easy Go?" Finanzarchiv, 59: 3-26.

Hines, J.R. 1996."Altered States: Taxes and the Location of Foreign Direct Investment in America," American Economic Review, 86: 1076-1094.

Javorcik, Beata Smarzynska. 2004. "Composition of foreign direct investment and protection of intellectual property rights in transition economies," European Economic Review, 48(1), pp. 39-62.

Kaufmann, Daniel; Aart Kraay and Pablo Zoido-Lobaton .1999a. "Aggregating Governance Indicators." World Bank Policy Research Working Paper No. 2195.

Kaufmann, Daniel, Art Kraay and Pablo Zoido-Lobaton 2002. "Governance Matters II: Updated Governance Indicators for 2000-01.

Keller, Wolfgang and Arik Levinson. 2002. "Pollution Abatement Costs and Foreign Direct Investment to U.S. States," Review of Economics and Statistics, 84(4).

Markusen, James R., 1995, The boundaries of multinational enterprises and the theory of international trade, Journal of Economic Perspectives. 9: 169-189.

Moran, Theodore. 1998. Foreign Direct Investment and Development. Institute for International Economics, Washington, DC.

Smarzynska, Beata and Shang-Jin Wei. 2001. "Pollution Havens and Foreign Direct Investment: Dirty Secret or Popular Myth?:” NBER Working Paper 8465.

Wei, Shang-Jin. 2000. "Local corruption and Global Capital Flows," Brookings Papers on Economic Activity, p. 303-354.

Wheeler, David and Ashoka Mody, 1992, "International Investment Location Decisions: The Case of US Firms," Journal of International Economics 33:57-76. 

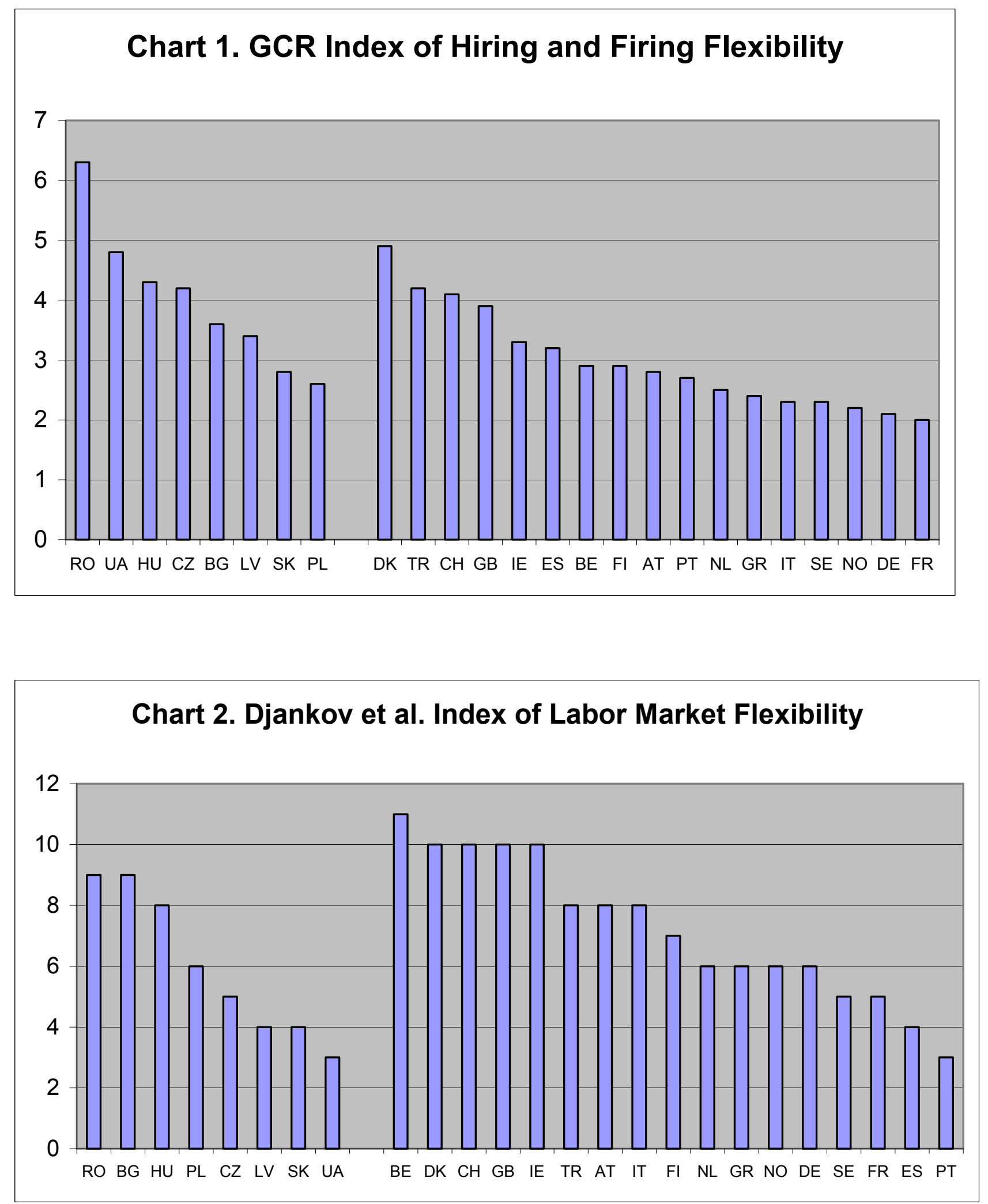


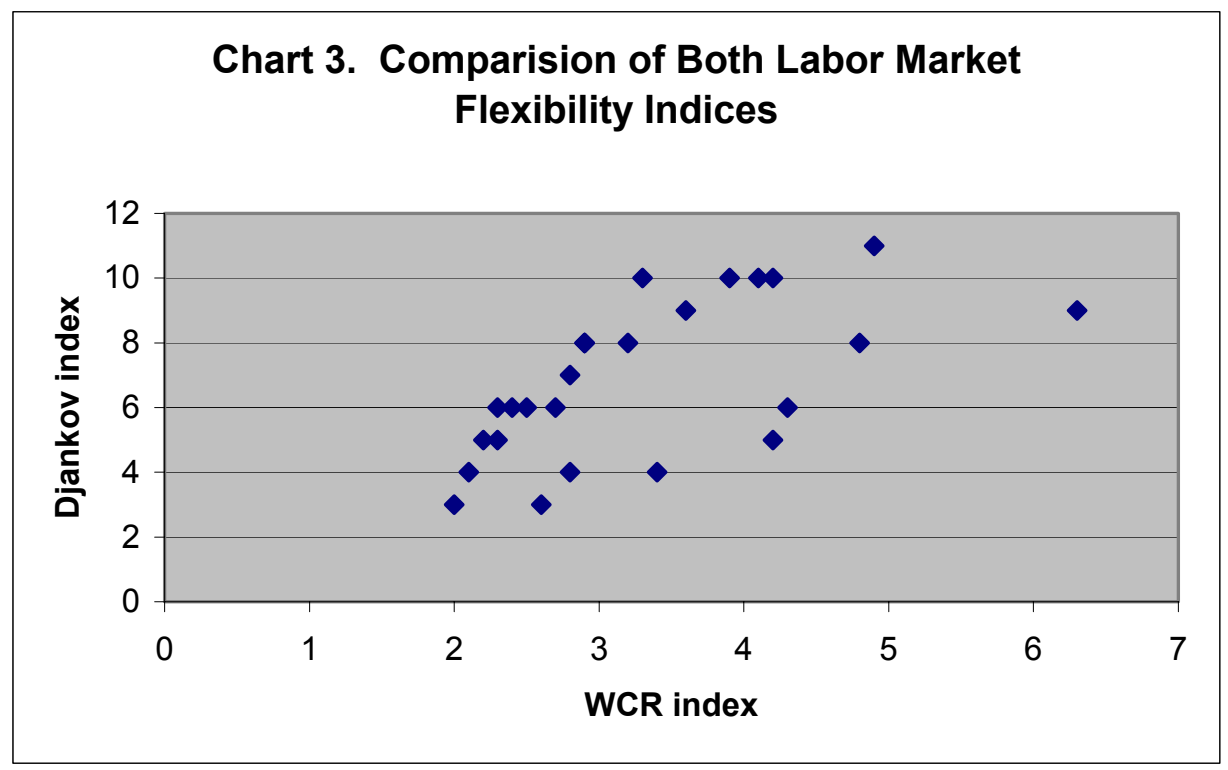




\begin{tabular}{|c|c|c|}
\hline Variable & Definition & Source \\
\hline FDI dummy & $\begin{array}{l}\text { A new subsidiary was created during } \\
1998-2001 \text { (see the text for details) }\end{array}$ & Amadeus database \\
\hline FDI volume & $\begin{array}{l}\text { The value of firm's investment into } \\
\text { its new foreign subsidiary (see the } \\
\text { text for details) }\end{array}$ & $\begin{array}{l}\text { Own calculations based on the } \\
\text { Amadeus database }\end{array}$ \\
\hline Firm's size & Value of total assets in US dollars & Amadeus database \\
\hline $\begin{array}{l}\text { Firm's international } \\
\text { experience }\end{array}$ & $\begin{array}{l}\text { Number of foreign subsidiaries in } \\
1998\end{array}$ & Amadeus database \\
\hline GDP per capita & Current US dollars & $\begin{array}{l}\text { World Bank World Development } \\
\text { Indicators Database }\end{array}$ \\
\hline Population size & & $\begin{array}{l}\text { World Bank World Development } \\
\text { Indicators Database }\end{array}$ \\
\hline FDI Restrictions & $\begin{array}{l}\text { Controls for the business climate in } \\
\text { the host country. The Index ranges } \\
\text { from } 0 \text { for no restrictions to } 4 \text { for } \\
\text { restrictions present in all areas. }\end{array}$ & Wei (2000) \\
\hline Property rights & $\begin{array}{l}\text { The index ranges from } 1 \text { for little or } \\
\text { no protection, to } 7 \text { for strongest } \\
\text { protection of property rights. }\end{array}$ & $\begin{array}{l}\text { Global Competitiveness Report } \\
\text { 2001-2002 }\end{array}$ \\
\hline Corporate tax rate & Expressed in percentages & PricewaterhouseCoopers \\
\hline Governance & $\begin{array}{l}\text { The index ranges from }-2.5 \text { for very } \\
\text { corrupt to } 2.5 \text { for best governed. }\end{array}$ & $\begin{array}{l}\text { Kaufman, Kraay and Zoido- } \\
\text { Lobaton (1999) }\end{array}$ \\
\hline $\begin{array}{l}\text { The Index of Flexibility of } \\
\text { Hiring and Firing Practices }\end{array}$ & $\begin{array}{l}\text { Ranges from } 0 \text { for a very rigid to } 7 \text { for } \\
\text { a very flexible labor market }\end{array}$ & $\begin{array}{l}\text { Global Competitiveness Report } \\
\text { 2001-2002 }\end{array}$ \\
\hline $\begin{array}{l}\text { Total Index on rules of } \\
\text { Dismissal }\end{array}$ & $\begin{array}{l}\text { Ranges from } 0 \text { for very strict to } 12 \text { for } \\
\text { very flexible rules }\end{array}$ & Djankov et al. (2003) \\
\hline $\begin{array}{l}\text { Index on the Flexibility of } \\
\text { Individual Dismissal } \\
\text { Procedures }\end{array}$ & $\begin{array}{l}\text { Ranges from } 0 \text { for very strict to } 12 \text { for } \\
\text { very flexible rules }\end{array}$ & Djankov et al. (2003) \\
\hline $\begin{array}{l}\text { Index of Flexibility of } \\
\text { Collective Dismissal } \\
\text { Procedures }\end{array}$ & $\begin{array}{l}\text { Ranges from } 0 \text { for very strict to } 12 \text { for } \\
\text { very flexible rules }\end{array}$ & Djankov et al. (2003) \\
\hline $\begin{array}{l}\text { Index on Notice and } \\
\text { Severance Payment }\end{array}$ & $\begin{array}{l}\text { Ranges from } 0 \text { for very strict to } 12 \text { for } \\
\text { very flexible rules }\end{array}$ & Djankov et al. (2003) \\
\hline
\end{tabular}




\begin{tabular}{|c|c|c|c|c|c|c|c|c|c|c|c|}
\hline \multirow[b]{2}{*}{ Country } & \multirow{2}{*}{$\begin{array}{c}\text { In GDP } \\
\text { per } \\
\text { capita }\end{array}$} & \multirow{2}{*}{ In Population } & \multirow[b]{2}{*}{ FDI restrictions } & \multirow{2}{*}{$\begin{array}{c}\text { Property } \\
\text { Rights } \\
\text { Protection } \\
\end{array}$} & \multirow[b]{2}{*}{ Tax rates } & \multirow{2}{*}{$\begin{array}{c}\text { KKZ } \\
\text { governance } \\
\text { index }\end{array}$} & \multirow[b]{2}{*}{$\begin{array}{l}\text { GCR Labor } \\
\text { index }\end{array}$} & \multicolumn{4}{|c|}{ Djankov Labor Indices } \\
\hline & & & & & & & & $\begin{array}{c}\text { Individual } \\
\text { dismissal }\end{array}$ & $\begin{array}{c}\text { Collective } \\
\text { dismissal }\end{array}$ & $\begin{array}{c}\text { Severance } \\
\text { payment }\end{array}$ & Overall index \\
\hline AT & 10.2 & 15.9 & 2 & 6.4 & 34 & 2.02 & 2.8 & 1 & 3 & 1 & 8 \\
\hline $\mathbf{B E}$ & 10.1 & 16.1 & 0 & 5.9 & 40 & 1.23 & 2.9 & 2 & 4 & 2 & 11 \\
\hline BG & 7.4 & 15.9 & 2 & 3.2 & 36 & -0.5 & 3.6 & 2 & 4 & 2 & 9 \\
\hline $\mathbf{C H}$ & 10.5 & 15.8 & 1 & 4.1 & 23 & 2.58 & 4.1 & 2 & 4 & 1 & 10 \\
\hline $\mathbf{C Z}$ & 8.6 & 16.1 & 1 & 4.4 & 35 & 0.35 & 4.2 & 1 & 3 & 0 & 5 \\
\hline DK & 10.4 & 15.5 & 2 & 6.4 & 34 & 2.57 & 4.9 & 2 & 3 & 2 & 10 \\
\hline ES & 9.6 & 17.5 & 2 & 5.9 & 35 & 1.58 & 3.2 & 1 & 1 & 1 & 4 \\
\hline FI & 10.1 & 15.5 & 2 & 6.5 & 28 & 2.55 & 2.9 & 2 & 2 & 1 & 7 \\
\hline FR & 10.1 & 17.9 & 2 & 6.4 & 33.3 & 1.75 & 2 & 1 & 1 & 1 & 5 \\
\hline GB & 10.1 & 17.9 & 0 & 6.3 & 30 & 2.32 & 3.9 & 2 & 4 & 2 & 10 \\
\hline GR & 9.3 & 16.2 & 3 & 5 & 40 & 0.85 & 2.4 & 2 & 3 & 1 & 6 \\
\hline HU & 8.5 & 16.1 & 0 & 5.3 & 18 & 0.69 & 4.3 & 2 & 3 & 1 & 8 \\
\hline IE & 10.1 & 15.1 & 1 & 6.1 & 32 & 2.15 & 3.3 & 2 & 3 & 2 & 10 \\
\hline IT & 9.9 & 17.9 & 2 & 6.2 & 37 & 1 & 2.3 & 2 & 2 & 1 & 8 \\
\hline $\mathbf{L V}$ & 7.9 & 14.7 & . & 4.3 & . & -0.1 & 3.4 & 0 & 1 & 2 & 4 \\
\hline NL & 10.1 & 16.6 & 0 & 6.5 & 35 & 2.48 & 2.5 & 0 & 2 & 2 & 6 \\
\hline NO & 10.4 & 15.3 & 2 & 5.9 & 28 & 2.34 & 2.2 & 1 & 1 & 2 & 6 \\
\hline PL & 8.3 & 17.5 & 1 & 4.6 & 32 & 0.49 & 2.6 & 1 & 2 & 1 & 6 \\
\hline PT & 9.3 & 16.1 & 1 & 5.3 & 36 & 1.55 & 2.7 & 2 & 1 & 0 & 3 \\
\hline RO & 7.4 & 16.9 & . & 4.5 & . & -0.38 & 6.3 & 2 & 4 & 2 & 9 \\
\hline $\mathbf{S E}$ & 10.2 & 16.0 & 0 & 5.9 & 28 & 2.54 & 2.3 & 1 & 1 & 1 & 5 \\
\hline $\mathbf{R U}$ & 7.19 & 18.8 & 4 & 2.4 & 35 & -0.69 & 4.7 & 0 & 1 & 0 & 2 \\
\hline SK & 8.2 & 15.5 & . & 5.2 & 40 & -0.08 & 2.8 & 1 & 2 & 0 & 4 \\
\hline TR & 8.0 & 18.0 & 2 & 4.2 & 33 & -0.01 & 4.2 & 2 & 3 & 0 & 8 \\
\hline $\mathbf{U A}$ & 6.4 & 17.7 & 4 & 3.2 & 30 & -0.89 & 4.8 & 1 & 0 & 1 & 3 \\
\hline Total & 9.2 & 15.9 & 1.3 & 5.4 & 32.6 & 1.2 & 3.3 & 1.4 & 2.4 & 1.2 & 6.8 \\
\hline
\end{tabular}


Table 2. Determinants of the Decision to Invest - Fixed Effect Logit Regression

\begin{tabular}{|c|c|c|c|c|c|c|c|c|c|c|c|}
\hline Host country GDP per capita & $\begin{array}{c}1.296^{* * *} \\
{[0.063]}\end{array}$ & $\begin{array}{c}1.421 * * * \\
{[0.064]}\end{array}$ & $\begin{array}{c}1.071 * * * \\
{[0.066]}\end{array}$ & $\begin{array}{c}1.213 * * * \\
{[0.063]}\end{array}$ & $\begin{array}{c}1.104 * * * \\
{[0.064]}\end{array}$ & $\begin{array}{c}1.082 * * * \\
{[0.064]}\end{array}$ & $\begin{array}{c}1.419 * * * \\
{[0.064]}\end{array}$ & $\begin{array}{c}1.063 * * * \\
{[0.066]}\end{array}$ & $\begin{array}{c}1.208^{* * *} \\
{[0.063]}\end{array}$ & $\begin{array}{c}1.076 * * * \\
{[0.064]}\end{array}$ & $\begin{array}{c}1.087 * * * \\
{[0.064]}\end{array}$ \\
\hline Host country population & $\begin{array}{c}1.326^{* * *} \\
{[0.020]}\end{array}$ & $\begin{array}{c}1.293 * * * \\
{[0.020]}\end{array}$ & $\begin{array}{c}1.315^{* * *} \\
{[0.020]}\end{array}$ & $\begin{array}{c}1.304 * * * \\
{[0.020]}\end{array}$ & $\begin{array}{c}1.289 * * * \\
{[0.020]}\end{array}$ & $\begin{array}{c}1.332 * * * \\
{[0.020]}\end{array}$ & $\begin{array}{c}1.299 * * * \\
{[0.020]}\end{array}$ & $\begin{array}{c}1.338^{* * *} \\
{[0.020]}\end{array}$ & $\begin{array}{c}1.301 * * * \\
{[0.020]}\end{array}$ & $\begin{array}{c}1.311^{* * *} \\
{[0.020]}\end{array}$ & $\begin{array}{c}1.379 * * * \\
{[0.021]}\end{array}$ \\
\hline FDI restrictions & $\begin{array}{c}-0.543 * * * \\
{[0.018]}\end{array}$ & $\begin{array}{c}-0.506^{* * *} \\
{[0.018]}\end{array}$ & $\begin{array}{c}-0.444 * * * \\
{[0.021]}\end{array}$ & $\begin{array}{c}-0.433 * * * \\
{[0.020]}\end{array}$ & $\begin{array}{c}-0.387 * * * \\
{[0.022]}\end{array}$ & $\begin{array}{c}-0.464 * * * \\
{[0.019]}\end{array}$ & $\begin{array}{c}-0.512 * * * \\
{[0.018]}\end{array}$ & $\begin{array}{c}-0.427 * * * \\
{[0.021]}\end{array}$ & $\begin{array}{c}-0.433 * * * \\
{[0.020]}\end{array}$ & $\begin{array}{c}-0.373 * * * \\
{[0.022]}\end{array}$ & $\begin{array}{c}-0.434 * * * \\
{[0.020]}\end{array}$ \\
\hline Property rights & $\begin{array}{c}0.038 \\
{[0.031]}\end{array}$ & $\begin{array}{c}0.140 * * * \\
{[0.031]}\end{array}$ & $\begin{array}{c}0.070^{* *} \\
{[0.031]}\end{array}$ & $\begin{array}{c}-0.02 \\
{[0.031]}\end{array}$ & $\begin{array}{c}0.149 * * * \\
{[0.031]}\end{array}$ & $\begin{array}{c}0.037 \\
{[0.031]}\end{array}$ & $\begin{array}{c}0.131 * * * \\
{[0.031]}\end{array}$ & $\begin{array}{c}0.018 \\
{[0.033]}\end{array}$ & $\begin{array}{c}-0.015 \\
{[0.032]}\end{array}$ & $\begin{array}{c}0.111 * * * \\
{[0.032]}\end{array}$ & $\begin{array}{l}-0.061 * \\
{[0.034]}\end{array}$ \\
\hline Corporate tax rate & $\begin{array}{c}0.016^{* * *} \\
{[0.005]}\end{array}$ & $\begin{array}{c}0.023 * * * \\
{[0.005]}\end{array}$ & $\begin{array}{c}0.027 * * * \\
{[0.005]}\end{array}$ & $\begin{array}{c}0.001 \\
{[0.005]}\end{array}$ & $\begin{array}{c}0.021 * * * \\
{[0.005]}\end{array}$ & $\begin{array}{c}0.054^{* * *} \\
{[0.006]}\end{array}$ & $\begin{array}{c}0.025 * * * \\
{[0.005]}\end{array}$ & $\begin{array}{c}0.035 * * * \\
{[0.006]}\end{array}$ & $\begin{array}{c}-0.001 \\
{[0.005]}\end{array}$ & $\begin{array}{c}0.027 * * * \\
{[0.005]}\end{array}$ & $\begin{array}{c}0.072 * * * \\
{[0.006]}\end{array}$ \\
\hline Governance & $\begin{array}{c}0.478 * * * \\
{[0.052]}\end{array}$ & $\begin{array}{c}0.343 * * * \\
{[0.053]}\end{array}$ & $\begin{array}{c}0.657 * * * \\
{[0.055]}\end{array}$ & $\begin{array}{c}0.331 * * * \\
{[0.053]}\end{array}$ & $\begin{array}{c}0.590 * * * \\
{[0.053]}\end{array}$ & $\begin{array}{c}0.897 * * * \\
{[0.060]}\end{array}$ & $\begin{array}{c}0.373 * * * \\
{[0.053]}\end{array}$ & $\begin{array}{c}0.732 * * * \\
{[0.058]}\end{array}$ & $\begin{array}{c}0.323 * * * \\
{[0.054]}\end{array}$ & $\begin{array}{c}0.658 * * * \\
{[0.054]}\end{array}$ & $\begin{array}{c}1.042 * * * \\
{[0.063]}\end{array}$ \\
\hline Transition country dummy (TE) & $\begin{array}{c}1.187^{* * *} \\
{[0.109]}\end{array}$ & $\begin{array}{c}1.236^{* * *} \\
{[0.108]}\end{array}$ & $\begin{array}{c}1.268 * * * \\
{[0.107]}\end{array}$ & $\begin{array}{c}0.931 * * * \\
{[0.113]}\end{array}$ & $\begin{array}{c}1.243 * * * \\
{[0.107]}\end{array}$ & $\begin{array}{c}1.719^{* * *} \\
{[0.116]}\end{array}$ & $\begin{array}{c}1.171^{* * *} \\
{[0.111]}\end{array}$ & $\begin{array}{c}1.478 * * * \\
{[0.115]}\end{array}$ & $\begin{array}{c}0.869 * * * \\
{[0.139]}\end{array}$ & $\begin{array}{c}1.291 * * * \\
{[0.107]}\end{array}$ & $\begin{array}{c}1.981 * * * \\
{[0.121]}\end{array}$ \\
\hline Difference in Hiring/Firing Rules & & $\begin{array}{c}-0.243 * * * \\
{[0.021]}\end{array}$ & & & & & $\begin{array}{c}-0.222 * * * \\
{[0.021]}\end{array}$ & & & & \\
\hline Difference in Hiring/Firing Rules * TE & & & & & & & $\begin{array}{c}-0.163 * * * \\
{[0.042]}\end{array}$ & & & & \\
\hline Difference in Dismissal Rules & & & $\begin{array}{c}-0.071 * * * \\
{[0.008]}\end{array}$ & & & & & $\begin{array}{c}-0.070 * * * \\
{[0.008]}\end{array}$ & & & \\
\hline Difference in Dismissal Rules Index *TE & & & & & & & & $\begin{array}{c}-0.089 * * * \\
{[0.018]}\end{array}$ & & & \\
\hline Difference in Severance Rules & & & & $\begin{array}{c}-0.449 * * * \\
{[0.038]}\end{array}$ & & & & & $\begin{array}{c}-0.456 * * * \\
{[0.039]}\end{array}$ & & \\
\hline Difference in Severance Rules * TE & & & & & & & & & $\begin{array}{c}0.057 \\
{[0.075]}\end{array}$ & & \\
\hline Difference in Collective Dismissal Rules & & & & & $\begin{array}{c}-0.194 * * * \\
{[0.016]}\end{array}$ & & & & & $\begin{array}{c}-0.187 * * * \\
{[0.016]}\end{array}$ & \\
\hline Difference in Collective Dismissal Rules * $\mathbf{T E}$ & & & & & & & & & & $\begin{array}{c}-0.221 * * * \\
{[0.034]}\end{array}$ & \\
\hline Difference in Individual Dismissal Rules & & & & & & $\begin{array}{c}-0.366 * * * \\
{[0.027]}\end{array}$ & & & & & $\begin{array}{c}-0.360 * * * \\
{[0.027]}\end{array}$ \\
\hline Difference in Individual Dismissal Rules * TE & & & & & & & & & & & $\begin{array}{c}-0.488 * * * \\
{[0.067]}\end{array}$ \\
\hline R-sq & 0.35 & 0.36 & 0.36 & 0.36 & 0.36 & 0.36 & 0.36 & 0.36 & 0.36 & 0.36 & 0.36 \\
\hline Chi-sq & 11,674 & 11,802 & 11,737 & 11,798 & 11,810 & 11,838 & 11,817 & 11,760 & 11,798 & 11,854 & 11,890 \\
\hline Prob $>$ Chi-sq & 0.00 & 0.00 & 0.00 & 0.00 & 0.00 & 0.00 & 0.00 & 0.00 & 0.00 & 0.00 & 0.00 \\
\hline No. of obs. & 77,792 & 77,748 & 77,682 & 77,682 & 77,682 & 77,682 & 77,748 & 77,682 & 77,682 & 77,682 & 77,682 \\
\hline
\end{tabular}


Table 3. Determinants of the Investment Volume - Tobit Regression

\begin{tabular}{|c|c|c|c|c|c|c|c|c|c|c|c|}
\hline Investing firm's size & $\begin{array}{c}0.065 * * * \\
{[0.005]}\end{array}$ & $\begin{array}{c}0.071 * * * \\
{[0.005]}\end{array}$ & $\begin{array}{c}0.074 * * * \\
{[0.005]}\end{array}$ & $\begin{array}{c}0.078^{* * *} \\
{[0.005]}\end{array}$ & $\begin{array}{c}0.077 * * * \\
{[0.005]}\end{array}$ & $\begin{array}{c}0.070 * * * \\
{[0.005]}\end{array}$ & $\begin{array}{c}0.071 * * * \\
{[0.005]}\end{array}$ & $\begin{array}{c}0.074 * * * \\
{[0.005]}\end{array}$ & $\begin{array}{c}0.078^{* * *} * \\
{[0.005]}\end{array}$ & $\begin{array}{c}0.077 * * * \\
{[0.005]}\end{array}$ & $\begin{array}{c}0.070^{* * *} * \\
{[0.005]}\end{array}$ \\
\hline International experience & $\begin{array}{c}0.090^{* * *} \\
{[0.005]}\end{array}$ & $\begin{array}{c}0.081 * * * \\
{[0.005]}\end{array}$ & $\begin{array}{c}0.076^{* * *} \\
{[0.005]}\end{array}$ & $\begin{array}{c}0.071 * * * \\
{[0.005]}\end{array}$ & $\begin{array}{c}0.072 * * * \\
{[0.005]}\end{array}$ & $\begin{array}{c}0.078 * * * \\
{[0.005]}\end{array}$ & $\begin{array}{c}0.081 * * * \\
{[0.005]}\end{array}$ & $\begin{array}{c}0.076 * * * \\
{[0.005]}\end{array}$ & $\begin{array}{c}0.071 * * * \\
{[0.005]}\end{array}$ & $\begin{array}{c}0.072 * * * \\
{[0.005]}\end{array}$ & $\begin{array}{c}0.078^{* * *} * \\
{[0.005]}\end{array}$ \\
\hline Source country GDP per capita & $\begin{array}{c}0.111^{* * *} \\
{[0.030]}\end{array}$ & $\begin{array}{c}0.119 * * * \\
{[0.030]}\end{array}$ & $\begin{array}{c}0.196 * * * \\
{[0.030]}\end{array}$ & $\begin{array}{c}0.315^{* * *} * \\
{[0.030]}\end{array}$ & $\begin{array}{c}0.109^{* * *} \\
{[0.030]}\end{array}$ & $\begin{array}{c}0.122 * * * \\
{[0.030]}\end{array}$ & $\begin{array}{c}0.119^{* * *} \\
{[0.030]}\end{array}$ & $\begin{array}{c}0.196^{* * *} \\
{[0.030]}\end{array}$ & $\begin{array}{c}0.317^{* * *} \\
{[0.030]}\end{array}$ & $\begin{array}{c}0.109^{* * *} \\
{[0.030]}\end{array}$ & $\begin{array}{c}0.122 * * * \\
{[0.030]}\end{array}$ \\
\hline Source country population & $\begin{array}{c}-0.015^{* *} \\
{[0.007]}\end{array}$ & $\begin{array}{l}-0.005 \\
{[0.007]}\end{array}$ & $\begin{array}{c}0.003 \\
{[0.007]}\end{array}$ & $\begin{array}{l}-0.007 \\
{[0.007]}\end{array}$ & $\begin{array}{c}0.017 * * \\
{[0.007]}\end{array}$ & $\begin{array}{c}0.023 * * * \\
{[0.007]}\end{array}$ & $\begin{array}{l}-0.004 \\
{[0.007]}\end{array}$ & $\begin{array}{c}0.003 \\
{[0.007]}\end{array}$ & $\begin{array}{l}-0.007 \\
{[0.007]}\end{array}$ & $\begin{array}{c}0.017 * * \\
{[0.007]}\end{array}$ & $\begin{array}{c}0.023 * * * \\
{[0.007]}\end{array}$ \\
\hline Host country GDP per capita & $\begin{array}{c}-0.288 * * * \\
{[0.018]}\end{array}$ & $\begin{array}{c}-0.255^{* * * *} \\
{[0.018]}\end{array}$ & $\begin{array}{c}-0.376 * * * \\
{[0.018]}\end{array}$ & $\begin{array}{c}-0.274 * * * \\
{[0.018]}\end{array}$ & $\begin{array}{c}-0.382 * * * \\
{[0.018]}\end{array}$ & $\begin{array}{c}-0.339 * * * \\
{[0.018]}\end{array}$ & $\begin{array}{c}-0.258 * * * \\
{[0.018]}\end{array}$ & $\begin{array}{c}-0.376 * * * \\
{[0.018]}\end{array}$ & $\begin{array}{c}-0.290 * * * \\
{[0.019]}\end{array}$ & $\begin{array}{c}-0.378 * * * \\
{[0.018]}\end{array}$ & $\begin{array}{c}-0.328 * * * \\
{[0.018]}\end{array}$ \\
\hline Host country population & $\begin{array}{c}0.432 * * * \\
{[0.006]}\end{array}$ & $\begin{array}{c}0.432 * * * \\
{[0.006]}\end{array}$ & $\begin{array}{c}0.467 * * * \\
{[0.006]}\end{array}$ & $\begin{array}{c}0.472 * * * \\
{[0.006]}\end{array}$ & $\begin{array}{c}0.466^{* * *} \\
{[0.006]}\end{array}$ & $\begin{array}{c}0.505^{* * *} \\
{[0.007]}\end{array}$ & $\begin{array}{c}0.432 * * * \\
{[0.006]}\end{array}$ & $\begin{array}{c}0.467 * * * \\
{[0.007]}\end{array}$ & $\begin{array}{c}0.466 * * * \\
{[0.007]}\end{array}$ & $\begin{array}{c}0.462 * * * \\
{[0.006]}\end{array}$ & $\begin{array}{c}0.516^{* * *} \\
{[0.007]}\end{array}$ \\
\hline FDI restrictions & $\begin{array}{c}-0.201 * * * \\
{[0.006]}\end{array}$ & $\begin{array}{c}-0.204 * * * \\
{[0.006]}\end{array}$ & $\begin{array}{c}-0.168 * * * \\
{[0.006]}\end{array}$ & $\begin{array}{c}-0.196 * * * \\
{[0.006]}\end{array}$ & $\begin{array}{c}-0.153^{* * *} \\
{[0.006]}\end{array}$ & $\begin{array}{c}-0.175^{* * *} * \\
{[0.006]}\end{array}$ & $\begin{array}{c}-0.208 * * * \\
{[0.006]}\end{array}$ & $\begin{array}{c}-0.169 * * * \\
{[0.006]}\end{array}$ & $\begin{array}{c}-0.199 * * * \\
{[0.006]}\end{array}$ & $\begin{array}{c}-0.157^{* * * *} \\
{[0.006]}\end{array}$ & $\begin{array}{c}-0.167 * * * * \\
{[0.006]}\end{array}$ \\
\hline Property rights & $\begin{array}{c}0.026^{* * * *} \\
{[0.009]}\end{array}$ & $\begin{array}{c}0.044 * * * \\
{[0.009]}\end{array}$ & $\begin{array}{c}0.030 * * * \\
{[0.009]}\end{array}$ & $\begin{array}{c}-0.020^{* *} \\
{[0.009]}\end{array}$ & $\begin{array}{c}0.067 * * * \\
{[0.009]}\end{array}$ & $\begin{array}{c}0.01 \\
{[0.009]}\end{array}$ & $\begin{array}{c}0.042 * * * \\
{[0.009]}\end{array}$ & $\begin{array}{c}0.031 * * * \\
{[0.009]}\end{array}$ & $\begin{array}{c}-0.017^{*} \\
{[0.009]}\end{array}$ & $\begin{array}{c}0.069 * * * \\
{[0.009]}\end{array}$ & $\begin{array}{l}-0.005 \\
{[0.009]}\end{array}$ \\
\hline Corporate tax rate & $\begin{array}{c}0.016^{* * *} \\
{[0.001]}\end{array}$ & $\begin{array}{c}0.018^{* * *} \\
{[0.001]}\end{array}$ & $\begin{array}{c}0.021 * * * \\
{[0.001]}\end{array}$ & $\begin{array}{c}0.010 * * * \\
{[0.001]}\end{array}$ & $\begin{array}{c}0.015^{* * *} \\
{[0.001]}\end{array}$ & $\begin{array}{c}0.027 * * * \\
{[0.001]}\end{array}$ & $\begin{array}{c}0.018 * * * \\
{[0.001]}\end{array}$ & $\begin{array}{c}0.020 * * * \\
{[0.001]}\end{array}$ & $\begin{array}{c}0.010^{* * *} \\
{[0.001]}\end{array}$ & $\begin{array}{c}0.016^{* * *} \\
{[0.001]}\end{array}$ & $\begin{array}{c}0.028 * * * \\
{[0.001]}\end{array}$ \\
\hline Governance & $\begin{array}{c}0.617 * * * \\
{[0.019]}\end{array}$ & $\begin{array}{c}0.589 * * * \\
{[0.019]}\end{array}$ & $\begin{array}{c}0.732 * * * \\
{[0.019]}\end{array}$ & $\begin{array}{c}0.566 * * * \\
{[0.018]}\end{array}$ & $\begin{array}{c}0.718^{* * *} \\
{[0.019]}\end{array}$ & $\begin{array}{c}0.817 * * * \\
{[0.020]}\end{array}$ & $\begin{array}{c}0.596 * * * \\
{[0.019]}\end{array}$ & $\begin{array}{c}0.731 * * * \\
{[0.019]}\end{array}$ & $\begin{array}{c}0.560^{* * *} \\
{[0.018]}\end{array}$ & $\begin{array}{c}0.712 * * * \\
{[0.019]}\end{array}$ & $\begin{array}{c}0.830 * * * \\
{[0.020]}\end{array}$ \\
\hline Transition country dummy (TE) & $\begin{array}{c}0.184 * * * \\
{[0.025]}\end{array}$ & $\begin{array}{c}0.178^{* * *} \\
{[0.025]}\end{array}$ & $\begin{array}{c}0.266^{* * * *} \\
{[0.025]}\end{array}$ & $\begin{array}{c}0.088^{* * *} \\
{[0.025]}\end{array}$ & $\begin{array}{c}0.221 * * * \\
{[0.025]}\end{array}$ & $\begin{array}{c}0.471 * * * \\
{[0.027]}\end{array}$ & $\begin{array}{c}0.166^{* * * *} \\
{[0.025]}\end{array}$ & $\begin{array}{c}0.263 * * * \\
{[0.027]}\end{array}$ & $\begin{array}{c}0.009 \\
{[0.034]}\end{array}$ & $\begin{array}{c}0.211^{* * * *} \\
{[0.025]}\end{array}$ & $\begin{array}{c}0.510^{* * *} \\
{[0.028]}\end{array}$ \\
\hline Difference in Hiring/Firing Rules & & $\begin{array}{c}-0.066 * * * \\
{[0.005]}\end{array}$ & & & & & $\begin{array}{c}-0.058 * * * \\
{[0.005]}\end{array}$ & & & & \\
\hline Difference in Hiring/Firing Rules * TE & & & & & & & $\begin{array}{c}-0.032 * * * \\
{[0.010]}\end{array}$ & & & & \\
\hline Difference in Dismissal Rules & & & $\begin{array}{c}-0.042 * * * \\
{[0.002]}\end{array}$ & & & & & $\begin{array}{c}-0.043 * * * \\
{[0.002]}\end{array}$ & & & \\
\hline Difference in Dismissal Rules Index *TE & & & & & & & & $\begin{array}{c}0.001 \\
{[0.004]}\end{array}$ & & & \\
\hline Difference in Severance Rules & & & & $\begin{array}{c}-0.241 * * * \\
{[0.007]}\end{array}$ & & & & & $\begin{array}{c}-0.258 * * * \\
{[0.009]}\end{array}$ & & \\
\hline Difference in Severance Rules * TE & & & & & & & & & $\begin{array}{c}0.055 * * * \\
{[0.016]}\end{array}$ & & \\
\hline Difference in Collective Dismissal Rules & & & & & $\begin{array}{c}-0.090 * * * \\
{[0.003]}\end{array}$ & & & & & $\begin{array}{c}-0.095 * * * \\
{[0.004]}\end{array}$ & \\
\hline Difference in Collective Dismissal Rules * TE & & & & & & & & & & $\begin{array}{c}0.020 * * * \\
{[0.007]}\end{array}$ & \\
\hline Difference in Individual Dismissal Rules & & & & & & $\begin{array}{c}-0.205 * * * \\
{[0.007]}\end{array}$ & & & & & $\begin{array}{c}-0.188 * * * \\
{[0.008]}\end{array}$ \\
\hline Difference in Individual Dismissal Rules * TE & & & & & & & & & & & $\begin{array}{c}-\mathbf{0 . 0 7 7} * * * \\
{[\mathbf{0 . 0 1 5}]}\end{array}$ \\
\hline R-sq & 0.04 & 0.04 & 0.04 & 0.05 & 0.04 & 0.04 & 0.04 & 0.04 & 0.05 & 0.04 & 0.04 \\
\hline Chi-sq & 7,857 & 8,050 & 8,445 & 9,018 & 8,598 & 8,672 & 8,059 & 8,445 & 9,030 & 8,607 & 8,696 \\
\hline Prob $>$ Chi-sq & 0.00 & 0.00 & 0.00 & 0.00 & 0.00 & 0.00 & 0.00 & 0.00 & 0.00 & 0.00 & 0.00 \\
\hline No. of obs. & 57,394 & 57,372 & 57,330 & 57,330 & 57,330 & 57,330 & 57,372 & 57,330 & 57,330 & 57,330 & 57,330 \\
\hline
\end{tabular}


Table 4. Determinants of the Decision to Invest - Fixed Effect Logit Regression - Three Additional Countries

\begin{tabular}{lccc}
\hline Host country GDP per capita & $0.920^{* * *}$ & $1.517^{* * *}$ & $1.478^{* * *}$ \\
Host country population & {$[0.057]$} & {$[0.062]$} & {$[0.062]$} \\
& $1.045^{* * *}$ & $1.140^{* * *}$ & $1.150^{* * *}$ \\
Property rights & {$[0.015]$} & {$[0.015]$} & {$[0.015]$} \\
& $0.131^{* * *}$ & $0.309^{* * *}$ & $0.326^{* * *}$ \\
Governance & {$[0.025]$} & {$[0.025]$} & {$[0.025]$} \\
& $0.738^{* * *}$ & $0.300^{* * *}$ & $0.279^{* * *}$ \\
Transition country dummy (TE) & {$[0.039]$} & {$[0.042]$} & {$[0.042]$} \\
& $1.240^{* * *}$ & $1.440^{* * *}$ & $1.505^{* * *}$ \\
& {$[0.086]$} & {$[0.090]$} & {$[0.088]$} \\
Difference in Hiring/Firing Rules & & & \\
& & $\mathbf{- 0 . 5 0 1 * * *}$ & $\mathbf{- 0 . 5 4 5 * * *}$ \\
Difference in Hiring/Firing Rules * TE & {$[\mathbf{0 . 0 1 7}]$} & {$[\mathbf{0 . 0 1 8}]$} \\
& & & $\mathbf{0 . 2 0 3 * * *}$ \\
& & & {$[\mathbf{0 . 0 3 1}]$}
\end{tabular}

\section{Difference in Dismissal Rules}

Difference in Dismissal Rules Index *TE

Difference in Severance Rules

Difference in Severance Rules * TE

Difference in Collective Dismissal Rules

Difference in Collective Dismissal Rules * TE

Difference in Individual Dismissal Rules

Difference in Individual Dismissal Rules * TE

\begin{tabular}{|c|c|c|c|c|c|c|c|}
\hline $\begin{array}{c}0.668^{* * * *} \\
{[0.058]}\end{array}$ & $\begin{array}{c}0.674 * * * \\
{[0.058]}\end{array}$ & $\begin{array}{c}1.024 * * * \\
{[0.060]}\end{array}$ & $\begin{array}{c}1.026^{* * *} \\
{[0.061]}\end{array}$ & $\begin{array}{c}0.845 * * * \\
{[0.059]}\end{array}$ & $\begin{array}{c}0.851^{* * *} \\
{[0.059]}\end{array}$ & $\begin{array}{c}0.876 * * * \\
{[0.058]}\end{array}$ & $\begin{array}{c}0.882^{* * *} \\
{[0.058]}\end{array}$ \\
\hline $1.095 * * *$ & $1.097 * * *$ & $0.996 * * *$ & $0.996 * * *$ & $1.038 * * *$ & $1.043 * * *$ & $1.111 * * *$ & $1.113 * * *$ \\
\hline$[0.016]$ & {$[0.016]$} & {$[0.015]$} & [0.016] & {$[0.016]$} & [0.016] & {$[0.016]$} & {$[0.016]$} \\
\hline $0.220 * * *$ & $0.212 * * *$ & 0.023 & 0.023 & $0.320 * * *$ & $0.307 * * *$ & $0.200 * * *$ & 0.190 *** \\
\hline$[0.025]$ & {$[0.026]$} & {$[0.027]$} & [0.027] & {$[0.025]$} & [0.026] & {$[0.025]$} & {$[0.026]$} \\
\hline $0.751 * * *$ & $0.750 * * *$ & $0.506^{* * *}$ & $0.506^{* * *}$ & $0.559 * * *$ & $0.564 * * *$ & $0.878 * * *$ & $0.875^{* * *}$ \\
\hline$[0.038]$ & {$[0.038]$} & {$[0.041]$} & {$[0.041]$} & [0.039] & [0.039] & [0.039] & [0.039] \\
\hline $1.232 * * *$ & $1.257^{* * *}$ & $1.108 * * *$ & $1.117^{* * *}$ & $1.105 * * *$ & $1.104 * * *$ & $1.732 * * *$ & $1.734 * * *$ \\
\hline [0.090] & [0.092] & [0.097] & [0.112] & [0.089] & [0.089] & [0.091] & [0.091] \\
\hline
\end{tabular}

$\begin{array}{cc}-\mathbf{0 . 2 1 0} * * * & -\mathbf{0 . 2 0 7} * * * \\ {[\mathbf{0 . 0 0 7}]} & {[\mathbf{0 . 0 0 7}]} \\ & -0.018 \\ & {[0.014]}\end{array}$

$\begin{array}{cc}\mathbf{- 0 . 4 1 1 * * *} & \mathbf{- 0 . 4 0 9 * * * *} \\ {[\mathbf{0 . 0 2 9}]} & {[\mathbf{0 . 0 3 1}]} \\ & -0.009 \\ & {[0.056]}\end{array}$

$\begin{array}{cc}-0.456 * * * & -0.448^{* * *} \\ {[0.013]} & {[0.013]} \\ & -0.071 * * * \\ & {[0.028]}\end{array}$

[0.028]

$\begin{array}{cc}-\mathbf{0 . 6 4 1} * * * & -\mathbf{0 . 6 3 2} * * * \\ {[\mathbf{0 . 0 2 5}]} & {[\mathbf{0 . 0 2 6}]} \\ & -0.067 \\ & {[0.053]}\end{array}$

\begin{tabular}{|c|c|c|c|c|c|c|c|c|c|c|c|}
\hline R-sq & 0.32 & 0.34 & 0.34 & 0.3 & 0.31 & 0.29 & 0.29 & 0.32 & 0.32 & 0.3 & 0.3 \\
\hline Chi-sq & 12,699 & 13,545 & 13,588 & 11,259 & 11,571 & 10,735 & 10,735 & 11,786 & 11,792 & 11,257 & 11,259 \\
\hline Prob $>$ Chi-sq & 0.00 & 0.00 & 0.00 & 0.00 & 0.00 & 0.00 & 0.00 & 0.00 & 0.00 & 0.00 & 0.00 \\
\hline No. of obs. & 106,440 & 106,380 & 106,380 & 92,118 & 92,118 & 92,118 & 92,118 & 92,118 & 92,118 & 92,118 & 92,118 \\
\hline
\end{tabular}




\begin{tabular}{|c|c|c|c|c|c|c|c|c|c|c|c|}
\hline Investing firm's size & $\begin{array}{c}0.050^{* * *} \\
{[0.004]}\end{array}$ & $\begin{array}{c}0.054 * * * \\
{[0.004]}\end{array}$ & $\begin{array}{c}0.054 * * * \\
{[0.004]}\end{array}$ & $\begin{array}{c}0.063^{* * * *} \\
{[0.005]}\end{array}$ & $\begin{array}{c}0.064 * * * \\
{[0.005]}\end{array}$ & $\begin{array}{c}0.065^{* * *} * \\
{[0.005]}\end{array}$ & $\begin{array}{c}0.065^{* * *} \\
{[0.005]}\end{array}$ & $\begin{array}{c}0.066^{* * *} \\
{[0.005]}\end{array}$ & $\begin{array}{c}0.067 * * * \\
{[0.005]}\end{array}$ & $\begin{array}{c}0.059^{* * *} \\
{[0.005]}\end{array}$ & $\begin{array}{c}0.060^{* * *} \\
{[0.005]}\end{array}$ \\
\hline International experience & $\begin{array}{c}0.072 * * * \\
{[0.004]}\end{array}$ & $\begin{array}{c}0.067 * * * \\
{[0.004]}\end{array}$ & $\begin{array}{c}0.067 * * * \\
{[0.004]}\end{array}$ & $\begin{array}{c}0.072 * * * \\
{[0.005]}\end{array}$ & $\begin{array}{c}0.072 * * * \\
{[0.005]}\end{array}$ & $\begin{array}{c}0.071 * * * \\
{[0.005]}\end{array}$ & $\begin{array}{c}0.071 * * * \\
{[0.005]}\end{array}$ & $\begin{array}{c}0.069 * * * \\
{[0.005]}\end{array}$ & $\begin{array}{c}0.068 * * * \\
{[0.005]}\end{array}$ & $\begin{array}{c}0.077 * * * \\
{[0.005]}\end{array}$ & $\begin{array}{c}0.076^{* * *} \\
{[0.005]}\end{array}$ \\
\hline Source country GDP per capita & $\begin{array}{c}0.093 * * * \\
{[0.023]}\end{array}$ & $\begin{array}{c}0.098 * * * \\
{[0.023]}\end{array}$ & $\begin{array}{c}0.099 * * * \\
{[0.023]}\end{array}$ & $\begin{array}{c}0.162 * * * \\
{[0.027]}\end{array}$ & $\begin{array}{c}0.164 * * * \\
{[0.027]}\end{array}$ & $\begin{array}{c}0.222 * * * \\
{[0.027]}\end{array}$ & $\begin{array}{c}0.227 * * * \\
{[0.027]}\end{array}$ & $\begin{array}{c}0.102 * * * \\
{[0.026]}\end{array}$ & $\begin{array}{c}0.102 * * * \\
{[0.026]}\end{array}$ & $\begin{array}{c}0.108 * * * \\
{[0.026]}\end{array}$ & $\begin{array}{c}0.110^{* * *} \\
{[0.026]}\end{array}$ \\
\hline Source country population & $\begin{array}{c}-0.019 * * * \\
{[0.005]}\end{array}$ & $\begin{array}{c}-0.013 * * \\
{[0.005]}\end{array}$ & $\begin{array}{c}-0.012 * * \\
{[0.005]}\end{array}$ & $\begin{array}{c}-0.004 \\
{[0.006]}\end{array}$ & $\begin{array}{c}-0.003 \\
{[0.006]}\end{array}$ & $\begin{array}{l}-0.012 * \\
{[0.006]}\end{array}$ & $\begin{array}{l}-0.011^{*} \\
{[0.006]}\end{array}$ & $\begin{array}{c}0.007 \\
{[0.006]}\end{array}$ & $\begin{array}{c}0.008 \\
{[0.006]}\end{array}$ & $\begin{array}{c}-0.001 \\
{[0.006]}\end{array}$ & $\begin{array}{c}0.002 \\
{[0.006]}\end{array}$ \\
\hline Host country GDP per capita & $\begin{array}{c}-0.111^{* * *} \\
{[0.013]}\end{array}$ & $\begin{array}{c}-0.064 * * * \\
{[0.014]}\end{array}$ & $\begin{array}{c}-0.094 * * * \\
{[0.014]}\end{array}$ & $\begin{array}{c}-0.125^{* * *} \\
{[0.016]}\end{array}$ & $\begin{array}{c}-0.161 * * * \\
{[0.016]}\end{array}$ & $\begin{array}{c}-0.061 * * * \\
{[0.016]}\end{array}$ & $\begin{array}{c}-0.084 * * * \\
{[0.017]}\end{array}$ & $\begin{array}{c}-0.152 * * * \\
{[0.016]}\end{array}$ & $\begin{array}{c}-0.157 * * * \\
{[0.016]}\end{array}$ & $\begin{array}{c}-0.085^{* * *} \\
{[0.016]}\end{array}$ & $\begin{array}{c}-0.132 * * * \\
{[0.016]}\end{array}$ \\
\hline Host country population & $\begin{array}{c}0.189 * * * \\
{[0.003]}\end{array}$ & $\begin{array}{c}0.193 * * * \\
{[0.003]}\end{array}$ & $\begin{array}{c}0.214 * * * \\
{[0.004]}\end{array}$ & $\begin{array}{c}0.257 * * * \\
{[0.005]}\end{array}$ & $\begin{array}{c}0.253 * * * \\
{[0.005]}\end{array}$ & $\begin{array}{c}0.261 * * * \\
{[0.005]}\end{array}$ & $\begin{array}{c}0.255^{* * *} * \\
{[0.005]}\end{array}$ & $\begin{array}{c}0.256 * * * \\
{[0.005]}\end{array}$ & $\begin{array}{c}0.254 * * * \\
{[0.005]}\end{array}$ & $\begin{array}{c}0.258^{* * *} * \\
{[0.005]}\end{array}$ & $\begin{array}{c}0.263 * * * \\
{[0.005]}\end{array}$ \\
\hline Property rights & $\begin{array}{c}0.123 * * * \\
{[0.007]}\end{array}$ & $\begin{array}{c}0.126 * * * \\
{[0.007]}\end{array}$ & $\begin{array}{c}0.146^{* * *} \\
{[0.007]}\end{array}$ & $\begin{array}{c}0.110^{* * *} \\
{[0.008]}\end{array}$ & $\begin{array}{c}0.130^{* * *} \\
{[0.008]}\end{array}$ & $\begin{array}{c}0.078 * * * \\
{[0.008]}\end{array}$ & $\begin{array}{c}0.080 * * * \\
{[0.008]}\end{array}$ & $\begin{array}{c}0.124 * * * \\
{[0.008]}\end{array}$ & $\begin{array}{c}0.144 * * * \\
{[0.008]}\end{array}$ & $\begin{array}{c}0.106^{* * *} * \\
{[0.008]}\end{array}$ & $\begin{array}{c}0.140 * * * \\
{[0.008]}\end{array}$ \\
\hline Governance & $\begin{array}{c}0.342 * * * \\
{[0.012]}\end{array}$ & $\begin{array}{c}0.312 * * * \\
{[0.013]}\end{array}$ & $\begin{array}{c}0.316^{* * *} \\
{[0.012]}\end{array}$ & $\begin{array}{c}0.369^{* * *} \\
{[0.013]}\end{array}$ & $\begin{array}{c}0.387 * * * \\
{[0.013]}\end{array}$ & $\begin{array}{c}0.309^{* * *} \\
{[0.013]}\end{array}$ & $\begin{array}{c}0.311^{* * *} \\
{[0.013]}\end{array}$ & $\begin{array}{c}0.390 * * * \\
{[0.013]}\end{array}$ & $\begin{array}{c}0.392 * * * \\
{[0.013]}\end{array}$ & $\begin{array}{c}0.367 * * * \\
{[0.013]}\end{array}$ & $\begin{array}{c}0.409 * * * \\
{[0.014]}\end{array}$ \\
\hline Transition country dummy (TE) & $\begin{array}{c}0.348 * * * \\
{[0.017]}\end{array}$ & $\begin{array}{c}0.366^{* * *} \\
{[0.017]}\end{array}$ & $\begin{array}{c}0.381 * * * \\
{[0.017]}\end{array}$ & $\begin{array}{c}0.358 * * * \\
{[0.020]}\end{array}$ & $\begin{array}{c}0.267 * * * \\
{[0.021]}\end{array}$ & $\begin{array}{c}0.314 * * * \\
{[0.020]}\end{array}$ & $\begin{array}{c}0.243 * * * \\
{[0.026]}\end{array}$ & $\begin{array}{c}0.324 * * * \\
{[0.020]}\end{array}$ & $\begin{array}{c}0.290 * * * \\
{[0.020]}\end{array}$ & $\begin{array}{c}0.420^{* * *} \\
{[0.021]}\end{array}$ & $\begin{array}{c}0.399 * * * \\
{[0.021]}\end{array}$ \\
\hline Difference in Hiring/Firing Rules & & $\begin{array}{c}-0.037 * * * \\
{[0.003]}\end{array}$ & $\begin{array}{c}-0.104 * * * \\
{[0.004]}\end{array}$ & & & & & & & & \\
\hline Difference in Hiring/Firing Rules * TE & & & $\begin{array}{c}0.146 * * * \\
{[0.007]}\end{array}$ & & & & & & & & \\
\hline Difference in Dismissal Rules & & & & $\begin{array}{c}-0.029 * * * \\
{[0.001]}\end{array}$ & $\begin{array}{c}-0.044 * * * \\
{[0.002]}\end{array}$ & & & & & & \\
\hline Difference in Dismissal Rules Index *TE & & & & & $\begin{array}{c}0.039 * * * \\
{[0.003]}\end{array}$ & & & & & & \\
\hline Difference in Severance Rules & & & & & & $\begin{array}{c}-0.140 * * * \\
{[0.006]}\end{array}$ & $\begin{array}{c}-0.163 * * * \\
{[0.008]}\end{array}$ & & & & \\
\hline Difference in Severance Rules * TE & & & & & & & $\begin{array}{c}0.052 * * * \\
{[0.012]}\end{array}$ & & & & \\
\hline Difference in Collective Dismissal Rules & & & & & & & & $\begin{array}{c}-0.066 * * * \\
{[0.003]}\end{array}$ & $\begin{array}{c}-0.101 * * * \\
{[0.003]}\end{array}$ & & \\
\hline Difference in Collective Dismissal Rules * TE & & & & & & & & & $\begin{array}{c}0.090 * * * \\
{[0.005]}\end{array}$ & & \\
\hline Difference in Individual Dismissal Rules & & & & & & & & & & $\begin{array}{c}-0.082 * * * \\
{[0.006]}\end{array}$ & $\begin{array}{c}-0.162 * * * \\
{[0.007]}\end{array}$ \\
\hline Difference in Individual Dismissal Rules * TE & & & & & & & & & & & $\begin{array}{c}0.187^{* * *} \\
{[0.011]}\end{array}$ \\
\hline R-sq & 0.02 & 0.02 & 0.03 & 0.03 & 0.03 & 0.03 & 0.03 & 0.03 & 0.03 & 0.03 & 0.03 \\
\hline Chi-sq & 6,004 & 6,130 & 6,624 & 5,797 & 5,975 & 5,975 & 5,993 & 5,980 & 6,263 & 5,591 & 5,855 \\
\hline Prob $>$ Chi-sq & 0.00 & 0.00 & 0.00 & 0.00 & 0.00 & 0.00 & 0.00 & 0.00 & 0.00 & 0.00 & 0.00 \\
\hline No. of obs. & 78,572 & 78,542 & 78,542 & 67,683 & 67,683 & 67,683 & 67,683 & 67,683 & 67,683 & 67,683 & 67,683 \\
\hline
\end{tabular}


Table 6. Determinants of the Decision to Invest - Fixed Effect Logit Regression - Services vs. Manufacturing

Host country GDP per capita

Host country population

FDI restrictions

Property rights

Corporate tax rate

Governance

Transition country dummy (TE)

Difference in Hiring/Firing Rules

Difference in Hiring/Firing Rules * Services

Difference in Dismissal Rules

Difference in Dismissal Rules Index * Services

Difference in Severance Rules

Difference in Severance Rules * Services

Difference in Collective Dismissal Rules

Difference in Collective Dismissal Rules * Services

Difference in Individual Dismissal Rules

Difference in Individual Dismissal Rules * Services

R-sq

Chi Sq

Prob $>$ Chi sq

No. of obs.

Standard errors in brackets; ${ }^{* *}$ significant at the $1 \%$ level, $* *$ at $5 \%$, $*$ at $10 \%$
$1.424 * * *$

$[0.064]-[0.064]$

$1.292 * * *$

$[0.020]$

$-0.505 * * *$

[0.018]

$0.139 * * *$

[0.031]

$0.023 * * *$

[0.005]

$0.335 * * *$

[0.053]

$1.235^{* * *}$

[0.108]

$-0.071 *$

[0.037]

$-0.232 * * *$

[0.040]

$-0.245 * * *$

[0.047]

$-0.164 * * *$

[0.051]

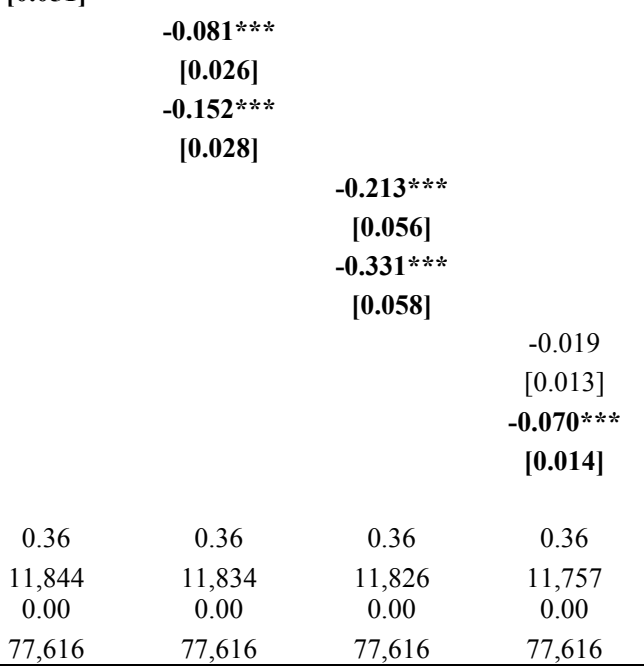

$1.114 * * * \quad 1.233 * * * \quad 1.080 * * *$

$[0.064] \quad[0.063] \quad[0.067]$

$1.330 * * * \quad 1.285^{* * *} \quad 1.302 * * * \quad 1.312^{* * *}$

$\left[\begin{array}{llll}0.020 & {[0.020]} & {[0.020]} & {[0.020]}\end{array}\right.$

$\begin{array}{llll}-0.464 * * * & -0.386 * * * & -0.428 * * * & -0.444 * * *\end{array}$

$\left[\begin{array}{llll}0.019 & {[0.022]} & {[0.020]} & {[0.021]}\end{array}\right.$

$\begin{array}{llll}0.037 & 0.149 * * * & -0.018 & 0.072 * *\end{array}$

$[0.031] \quad[0.031] \quad[0.031] \quad[0.031]$

$\begin{array}{llll}0.054^{* * *} & 0.021^{* * *} & 0 & 0.026^{* * *}\end{array}$

$\left[\begin{array}{llll}0.006 & {[0.005]} & {[0.005]} & {[0.005]}\end{array}\right.$

$0.891 * * * \quad 0.579 * * * \quad 0.316 * * * \quad 0.647 * * *$

$\left[\begin{array}{llll}0.060] & {[0.053]} & {[0.053]} & {[0.055]}\end{array}\right.$

$\begin{array}{llll}1.709^{* * *} & 1.246 * * * & 0.942 * * * & 1.267 * * *\end{array}$

$\left[\begin{array}{llll}0.116 & {[0.107]} & {[0.113]} & {[0.108]}\end{array}\right.$

\begin{tabular}{ccccc}
0.36 & 0.36 & 0.36 & 0.36 & 0.36 \\
11,831 & 11,844 & 11,834 & 11,826 & 11,757 \\
0.00 & 0.00 & 0.00 & 0.00 & 0.00 \\
77,682 & 77,616 & 77,616 & 77,616 & 77,616 \\
\hline
\end{tabular}


Table 7. Determinants of the Investment Volume - Tobit Regression - Services vs. Manufacturing

\begin{tabular}{|c|c|c|c|c|c|}
\hline Investing firm's size & $\begin{array}{c}0.071 * * * \\
{[0.005]}\end{array}$ & $\begin{array}{c}0.071 * * * \\
{[0.005]}\end{array}$ & $\begin{array}{c}0.078^{* * *} \\
{[0.005]}\end{array}$ & $\begin{array}{c}0.077 * * * \\
{[0.005]}\end{array}$ & $\begin{array}{c}0.074 * * * \\
{[0.005]}\end{array}$ \\
\hline International experience & $\begin{array}{c}0.080^{* * *} \\
{[0.005]}\end{array}$ & $\begin{array}{c}0.077^{* * *} \\
{[0.005]}\end{array}$ & $\begin{array}{c}0.071 * * * \\
{[0.005]}\end{array}$ & $\begin{array}{c}0.071 * * * \\
{[0.005]}\end{array}$ & $\begin{array}{c}0.075^{* * *} \\
{[0.005]}\end{array}$ \\
\hline Source country GDP per capita & $\begin{array}{c}0.120 * * * \\
{[0.030]}\end{array}$ & $\begin{array}{c}0.124 * * * \\
{[0.030]}\end{array}$ & $\begin{array}{c}0.312 * * * \\
{[0.030]}\end{array}$ & $\begin{array}{c}0.107 * * * \\
{[0.030]}\end{array}$ & $\begin{array}{c}0.194 * * * \\
{[0.030]}\end{array}$ \\
\hline Source country population & $\begin{array}{c}-0.004 \\
{[0.007]}\end{array}$ & $\begin{array}{c}0.024 * * * \\
{[0.007]}\end{array}$ & $\begin{array}{c}-0.006 \\
{[0.007]}\end{array}$ & $\begin{array}{c}0.018 * * * \\
{[0.007]}\end{array}$ & $\begin{array}{c}0.005 \\
{[0.007]}\end{array}$ \\
\hline Host country GDP per capita & $\begin{array}{c}-0.254 * * * \\
{[0.018]}\end{array}$ & $\begin{array}{c}-0.339 * * * \\
{[0.018]}\end{array}$ & $\begin{array}{c}-0.273 * * * \\
{[0.018]}\end{array}$ & $\begin{array}{c}-0.382 * * * \\
{[0.018]}\end{array}$ & $\begin{array}{c}-0.375^{* * *} \\
{[0.018]}\end{array}$ \\
\hline Host country population & $\begin{array}{c}0.432 * * * \\
{[0.006]}\end{array}$ & $\begin{array}{c}0.506^{* * *} \\
{[0.007]}\end{array}$ & $\begin{array}{c}0.472 * * * \\
{[0.006]}\end{array}$ & $\begin{array}{c}0.466^{* * *} \\
{[0.006]}\end{array}$ & $\begin{array}{c}0.468 * * * \\
{[0.006]}\end{array}$ \\
\hline FDI restrictions & $\begin{array}{c}-0.204 * * * \\
{[0.006]}\end{array}$ & $\begin{array}{c}-0.174 * * * \\
{[0.006]}\end{array}$ & $\begin{array}{c}-0.196 * * * \\
{[0.006]}\end{array}$ & $\begin{array}{c}-0.153 * * * \\
{[0.006]}\end{array}$ & $\begin{array}{c}-0.168 * * * \\
{[0.006]}\end{array}$ \\
\hline Property rights & $\begin{array}{c}0.045^{* * *} \\
{[0.009]}\end{array}$ & $\begin{array}{c}0.01 \\
{[0.009]}\end{array}$ & $\begin{array}{c}-0.020 * * \\
{[0.009]}\end{array}$ & $\begin{array}{c}0.067 * * * \\
{[0.009]}\end{array}$ & $\begin{array}{c}0.030 * * * \\
{[0.009]}\end{array}$ \\
\hline Corporate tax rate & $\begin{array}{c}0.018^{* * *} \\
{[0.001]}\end{array}$ & $\begin{array}{c}0.027 * * * \\
{[0.001]}\end{array}$ & $\begin{array}{c}0.010 * * * \\
{[0.001]}\end{array}$ & $\begin{array}{c}0.016^{* * *} \\
{[0.001]}\end{array}$ & $\begin{array}{c}0.021 * * * \\
{[0.001]}\end{array}$ \\
\hline Governance & $\begin{array}{c}0.589 * * * \\
{[0.019]}\end{array}$ & $\begin{array}{c}0.818^{* * *} \\
{[0.020]}\end{array}$ & $\begin{array}{c}0.565 * * * \\
{[0.018]}\end{array}$ & $\begin{array}{c}0.718 * * * \\
{[0.019]}\end{array}$ & $\begin{array}{c}0.732 * * * \\
{[0.019]}\end{array}$ \\
\hline Transition country dummy (TE) & $\begin{array}{c}0.178 * * * \\
{[0.025]}\end{array}$ & $\begin{array}{c}0.473 * * * \\
{[0.027]}\end{array}$ & $\begin{array}{c}0.088 * * * \\
{[0.025]}\end{array}$ & $\begin{array}{c}0.221 * * * \\
{[0.025]}\end{array}$ & $\begin{array}{c}0.267 * * * \\
{[0.025]}\end{array}$ \\
\hline Difference in Hiring/Firing Rules & $\begin{array}{c}-0.038 * * * \\
{[0.009]}\end{array}$ & & & & \\
\hline Difference in Hiring/Firing Rules * Services & $\begin{array}{c}-0.037 * * * \\
{[0.010]}\end{array}$ & & & & \\
\hline Difference in Dismissal Rules & & $\begin{array}{c}-0.170 * * * \\
{[0.013]}\end{array}$ & & & \\
\hline Difference in Dismissal Rules Index *Services & & $\begin{array}{c}-0.047 * * * \\
{[0.014]}\end{array}$ & & & \\
\hline Difference in Severance Rules & & & $\begin{array}{c}-0.208 * * * \\
{[0.013]}\end{array}$ & & \\
\hline Difference in Severance Rules * Services & & & $\begin{array}{c}-0.044 * * * \\
{[0.014]}\end{array}$ & & \\
\hline Difference in Collective Dismissal Rules & & & & $\begin{array}{c}-0.068 * * * \\
{[0.006]}\end{array}$ & \\
\hline Difference in Collective Dismissal Rules * Services & & & & $\begin{array}{c}-0.029 * * * \\
{[0.007]}\end{array}$ & \\
\hline Difference in Individual Dismissal Rules & & & & & $\begin{array}{c}-0.031 * * * \\
{[0.003]}\end{array}$ \\
\hline Difference in Individual Dismissal Rules * Services & & & & & $\begin{array}{c}-0.014 * * * \\
{[0.003]}\end{array}$ \\
\hline Services Dummy & $\begin{array}{c}-0.018 \\
{[0.013]}\end{array}$ & $\begin{array}{c}0.00 \\
{[0.012]}\end{array}$ & $\begin{array}{c}0.015 \\
{[0.014]}\end{array}$ & $\begin{array}{c}0.011 \\
{[0.013]}\end{array}$ & $\begin{array}{c}0.01 \\
{[0.013]}\end{array}$ \\
\hline R-sq & 0.04 & 0.04 & 0.05 & 0.04 & 0.04 \\
\hline Chi-sq & 8,063 & 8,683 & 9,028 & 8,615 & 8,461 \\
\hline Prob $>$ Chi-sq & 0.00 & 0.00 & 0.00 & 0.00 & 0.00 \\
\hline No. of obs. & 57,335 & 57,293 & 57,293 & 57,293 & 57,293 \\
\hline
\end{tabular}

Standard errors in brackets; $* * *$ significant at the $1 \%$ level, $* *$ at $5 \%, *$ at $10 \%$ 